VANESSA HAGGIE

\title{
BUT NAMES WILL NEVER HURT ME: EXTENDING HATE SPEECH LEGISLATION TO PROTECT GENDER AND SEXUAL MINORITIES IN NEW ZEALAND
}

LAWS 5822013

RESEARCH PAPER

FACULTY OF LAW

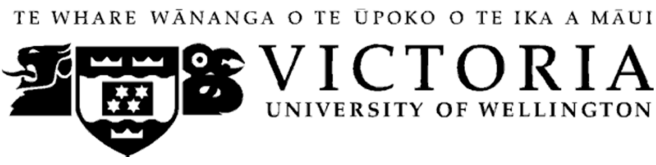

\begin{abstract}
:
Hate speech legislation involves a fundamental conflict with the right to freedom of expression. However, it is a conflict that can be justified in a constitutional framework in which free speech is not paramount and can be balanced against other rights and freedoms. This paper discusses the concept of "hate speech" legislation, the conflict between freedom of expression and hate speech censorship, and ways in which these seemingly-incompatible concepts might be harmonised. It considers, drawing on legislation and case law from other jurisdictions, and in light of the Marriage (Definition of Marriage) Amendment Act 2013, the possibility of extending such legislation to protect gender and sexual minorities in New Zealand, and suggests a potential framework for such legislative change.

Any provision concerning hate speech must avoid overreaching into the realm of free expression. As a result, 'hate speech' should be clearly defined and narrowly focussed in scope, as words or matter which "exposes or tends to expose to hatred or contempt" the minority group at which the protection is aimed. In New Zealand's constitutional/rights framework, this limitation on freedom of expression can be justified as reasonable and appropriate. While hate speech legislation does create a conflict with freedom of expression, to protect hate speech at the risk of perpetuating harm, discrimination, marginalisation and silencing is not appropriate. It sends the message that the voice of hate speakers is worth more than that of minorities, and undervalues the dignity and social assurance of those minority groups as valued members of society.
\end{abstract}

This paper comprises 12,000 words not including the abstract, contents, bibliography or appendices. 


\section{CONTENTS}

I Introduction

II Balancing Freedom of Expression and Hate Speech

A New Zealand

B Overseas Jurisdictions

$1 \quad$ Australia

2 Canada

3 South Africa

$4 \quad$ United Kingdom

$5 \quad$ United States

C Justifying Hate Speech Censorship

1 Discrimination

2 Denying speech

3 Harm

$4 \quad$ Denying dignity and assurance

D Defining Hate Speech

III Legislating Against Hate Speech in New Zealand

A Existing Censorship in New Zealand

1 Films, Videos, and Publications Classification Act 1993 and the Office of Film and Literature

2 Limitations on OFLC power

B Extending Hate Speech Legislation

$1 \quad$ Proposed legislation

a) Human Rights Act provisions

b) FVPCA provisions

2 Balancing against the Bill of Rights

$3 \quad$ What might be covered?
a) Political speech

b) Humour

4 Alternatives to Civil Legislation

a) Marketplace of ideas

b) Subsidised marketplace of ideas

c) Criminalising hate speech

\section{Conclusion}

$V \quad$ Bibliography

VI Appendices

A Appendix 1

B Appendix 2 


\section{Introduction}

"I disapprove of what you say, but I will defend to the death your right to say it."

This axiom illustrates a liberal approach to freedom of expression, a fundamental underpinning of a free society. When a citizen exercises that freedom to advocate for denying rights, dignity, respect, or life, however, should that expression still be protected within the law? Expecting vulnerable minorities to stoically accept the impact of hate speech, in the quest for untrammelled free expression, may perpetuate marginalisation and discrimination.

In this paper I discuss the concept of 'hate speech' legislation, the conflict between freedom of expression and hate speech censorship, and ways in which these seeminglyincompatible concepts might be harmonised. What is considered 'hate speech' is a subject of much discussion in different jurisdictions and among differing academic perspectives, and this paper will expand upon these different conceptions and definitions. However, it is useful at the outset to establish a general definition of the term, as it will be used extensively. Hate speech goes further than unpleasant speech which might cause offence or hurt feelings. 'Hate speech' is therefore used as a general term to cover the type of expression that can be variously described as 'vilification', 'exposing to hatred', 'expressing serious contempt', or 'exciting hostility'.

This paper considers, drawing on legislation and case law from other jurisdictions, and in light of the recent Marriage (Definition of Marriage) Amendment Act 2013, the possibility of extending such legislation to protect gender and sexual minorities in New Zealand, and suggests a potential framework for such legislative change. The paper uses the inclusive terminology "gender and sexual minorities" (GSM), rather than the common 'LGBT' (Lesbian, Gay, Bisexual, Transgender). The term is intended to act as a non-exclusive descriptor which also encompasses discrimination faced by gender minorities such as women who are not by default included in the LGBT spectrum.

\section{Balancing Freedom of Expression and Hate Speech}

Hate speech legislation involves a fundamental conflict with the right to freedom of expression. However, the interaction between these concepts can be reconciled to some extent. This section examines various jurisdictions' approaches to such a balancing act,

\footnotetext{
${ }^{1}$ While this axiom is popularly attributed to Voltaire, it was in fact written by Evelyn Beatrice Hall The Friends of Voltaire (London, 1906) at 199; see Burdette Kinne "Voltaire Never Said It!" (1943) 58(7) Modern Language Notes at 534.
} 
and considers how 'hate speech' can be interpreted and how censorship might be justified.

\section{A New Zealand legislation}

While New Zealand legislation currently does not address hate speech against gender or sexual minorities, it does include various provisions that act as hate speech legislation. Section 61 of the Human Rights Act 1993 covers 'racial disharmony' and makes it unlawful to "publish or distribute ... written matter which is threatening, abusive, or insulting", to "use in any public place ... words which are threatening, abusive or insulting", or to use insulting, abusive or threatening words if they are "reasonably likely to be published" 4 where those words are "likely to excite hostility against or bring into contempt any group of persons ... on the ground of the colour, race, or ethnic or national origins of that group of persons"5. Complaints can be made to the Human Rights Commission, ${ }^{6}$ and these complaints may be considered by the Human Rights Review Tribunal ${ }^{7}$ and remedies granted including an order restraining the defendant from repeating the breach $^{8}$ or damages. ${ }^{9}$

Section 131 further prohibits 'inciting racial disharmony', which is defined as a similar set of behaviour as s 61 (publishing threatening, insulting, or abusive words) but also requires that the offender is acting with "intent to excite hostility or ill-will against, or bring into contempt or ridicule, any group of persons in New Zealand on the ground of the colour, race, or ethnic or national origins of that group". This offence is punishable by a fine of up to $\$ 7000$ or three months imprisonment, but can only be prosecuted with the consent of the Attorney-General, making it not often used in practice.

The Bill of Rights Act 1990 grants freedom of expression in s 14. However, it also grants freedom from discrimination in $\mathrm{s} 19$. The existing racial disharmony provisions are centred within an anti-discrimination framework, indicating that they are intended to serve the purposes of freedom from discrimination under the Bill of Rights Act.

\section{B Overseas Jurisdictions}

\footnotetext{
${ }^{2}$ Human Rights Act 1993, s 61(1)(a).

${ }^{3}$ Section 61(1)(b).

${ }^{4}$ Section 61(1)(c).

5 Section 61(1).

${ }^{6}$ Section 76(2)(a).

7 Section 92B.

${ }^{8}$ Section 92I(3)(b).

${ }^{9}$ Section 92I(3)(c).
} 


\section{$1 \quad$ Australia}

Hate speech legislation in Australia is complex due first to the relationship between state and federal legislation, and secondly because Australia has no federal or constitutionally entrenched Bill of Rights or Human Rights Act and thus no fundamental freedom of expression. Despite this lack, the Australian courts have implied a constitutional right to freedom of political communication. ${ }^{10}$ However as was made clear in Lange v Australian Broadcasting Corporation, the rights implied "do not confer personal rights on individuals. Rather they preclude the curtailment of the protected freedom by the exercise of legislative or executive power." ${ }^{11}$ Furthermore, the freedom is not absolute, but limited to "what is necessary for the effective operation [of representative responsible government]."12 As a result, Australian freedom of expression is significantly limited.

Australia's federal legislation does prohibit hate speech to some extent. The Racial Hatred Act 1995 added clauses into the original 1975 Racial Discrimination Act, making it unlawful to do a public act if "the act is reasonably likely, in all the circumstances, to offend, insult, humiliate or intimidate another person or a group of people." 13 However, the legislation only prohibits hate speech on the basis of "the race, colour or national or ethnic origin of the other person or of some or all of the people in the group. $" 14$ Hate speech against other minorities, such as GSM groups, is therefore not prohibited under federal Australian law.

Various Australian states have passed hate speech legislation which go further than federal law. The New South Wales Anti-Discrimination Act 1977 makes racial vilification unlawful as in the federal $\mathrm{Act}^{15}$ but also prohibits homosexual vilification ${ }^{16}$ under the Anti-Discrimination (Homosexual Vilification) Act 1993. This includes a criminal offence of "serious homosexual vilification" that requires the element of threatening physical harm or inciting others to threaten physical harm. ${ }^{17}$

\footnotetext{
${ }^{10}$ See Theophanous $v$ Herald \& Weekly Times Ltd (1994) 182 CLR 104; Stephens $v$ West Australian Newspapers Ltd (1994) 182 CLR 211; Lange v Australian Broadcasting Corporation (1997) 189 CLR 520.

${ }^{11}$ Lange $v A B C$, above $\mathrm{n} 10$, at [44].

${ }^{12}$ Lange $v A B C$, above $\mathrm{n} 10$, at [48]-[49].

${ }^{13}$ Racial Discrimination Act 1975 (Australia), s 18C(1)(a).

${ }^{14}$ Section (1)(b).

${ }^{15}$ New South Wales Anti-Discrimination Act 1977 (Australia), s 20C.

${ }^{16}$ Section 49ZT.

${ }^{17}$ Section 49ZTA.
} 
The Transgender (Anti-Discrimination and other Acts Amendment) Act 1996 amended the Act so that it also prohibits transgender vilification ${ }^{18}$ and serious transgender vilification $^{19}$ in the same way. A recent case considered what might be classed as transgender vilification; the respondent, in a conversation with a workmate, had said about a transgender colleague, "It's a fucking trannie taking hormones but still got tits and a box. I'll fucking punch its head through its own car window, cunt."20 Although the complaint failed as the speech was found not to be 'public', the court found that the words: $:^{21}$

$[\mathrm{C}]$ ould be seen as tending to encourage members of the public who heard the comments to treat transgender persons as less than fully human and to suggest that physical abuse of such persons was justifiable.

The Court therefore considered that if the expression had been public, such expression was capable of being considered transgender vilification, or 'hate speech'. ${ }^{22}$

Both criminal 'serious vilification' offences bear a maximum penalty of six months imprisonment, but can only be prosecuted with the consent of the Attorney-General. ${ }^{23}$ The lesser conduct of vilification can be pursued civilly in the Disputes Tribunal ${ }^{24}$ and include a defence on the grounds that the act was done "reasonably and in good faith, for academic, artistic, scientific, research or religious discussion or instruction purposes or for other purposes in the public interest, including discussion or debate about and expositions of any act or matter." 25

The Queensland Anti-Discrimination Act 1991 also protects against vilification. While the NSW Act separates each type of vilification, the Queensland Act makes vilification on the grounds of "race, religion, sexuality or gender identity" unlawful. ${ }^{26}$ It too includes a defence on the grounds of reasonable, good faith behaviour in the public interest, but excludes religion as a defence. ${ }^{27}$ The Queensland Act also includes an offence of "serious racial, religious, sexuality or gender identity vilification", with the same requirements regarding threatening physical harm, and the same maximum

\footnotetext{
${ }^{18}$ Section 38S.

${ }^{19}$ Section 38T.

${ }^{20}$ Barry $v$ Futter [2011] NSWADT 205 at [34].

${ }^{21}$ At [85].

${ }^{22}$ At [87].

${ }^{23}$ New South Wales Anti-Discrimination Act 1977, above n 15, ss 38T(2), 49ZTA(2).

${ }^{24}$ Section 108.

${ }^{25}$ Sections 38S(2)(c), 49ZT(2)(c).

${ }^{26}$ Queensland Anti-Discrimination Act 1991 (Australia), s 124A(1).

${ }^{27}$ Section 124(2)(c).
} 
penalty, as the NSW legislation. ${ }^{28}$ In Owen $v$ Menzies, the Supreme Court of Queensland found that a bisexual person may have standing to complain of vilification against homosexuals. $^{29}$

Similarly to NSW and Queensland, the Tasmania Anti-Discrimination Act 1998 prohibits inciting hatred on the grounds of race, disability, sexual orientation or lawful sexual activity, or religious belief. ${ }^{30}$ Whereas both NSW and Queensland protect gender minorities (NSW referring to 'transgender individuals' and Queensland listing the ground of gender identity), the Tasmanian Act lacks protection on the basis of gender identity. This is a lack that could be addressed to further protect gender minorities.

In both NSW and Queensland, the courts have been required to consider whether the anti-vilification legislation infringed or was inconsistent with the implied constitutional right to freedom of political communication. The courts applied the test first introduced by the High Court in Lange $v A B C$, which determines whether a statutory provision "impermissibly burdens the implied freedom of political communication" 31 and which the court in Owen $v$ Menzies laid out as follows: ${ }^{32}$

$[\mathrm{T}]$ he first question is whether, in its terms, operation or effect, s 124A effectively burdens freedom of communication about government or political matters. If it does not, it is not unconstitutional. If it does burden the freedom, the second question is whether $\mathrm{s} 124 \mathrm{~A}$ is reasonably appropriate and adapted to serve a legitimate end in a manner compatible with the maintenance of the constitutionally prescribed system of government.

In Sunol v Collier (No 2) the NSW Court of Appeal was asked to consider "whether s 49ZT of the Anti-Discrimination Act 1977 (NSW) should be read down so as not to infringe or be construed so as to conform with the constitutional implication of freedom of communication about government and political matters." 33

The court found that while s $49 \mathrm{ZT}$ did burden freedom of political communication, it was reasonable, legitimate and constitutionally compatible. ${ }^{34}$ The court made clear that freedom of communication was not absolute but "an implication of freedom under the

\footnotetext{
${ }^{28}$ Section 131A.

${ }^{29}$ Owen v Menzies (2012) QCA 170 at [88].

${ }^{30}$ Tasmania Anti-Discrimination Act 1998 (Australia), s 19.

${ }^{31}$ Owen v Menzies, above n 29, at [70].

${ }^{32}$ At [70], referring to Lange $v A B C$, above n 10, at [49].

${ }^{33}$ Sunol v Collier (No 2) [2012] NSWCA 44.

${ }^{34}$ Sunol v Collier (No 2), above n 33, at [46].
} 
law of an ordered and democratic society." 35 It also stressed that the question was not whether the legislative choice made by Parliament was the most preferable or desirable, but whether it was a reasonable means of achieving its purpose, in light of the burden placed on the constitutional freedom of communication. ${ }^{36}$

Although the respondent argued that restricting his genuinely-held views was constitutionally invalid and constrained his ability to engage in political debate, the court made clear that even political debate may validly be restricted by anti-vilification laws: ${ }^{37}$

It seems to me plain that seeking to prevent homosexual vilification is a legitimate end of government. A law seeking to prevent the incitement of such conduct seems to me compatible with the maintenance of the constitutionally provided system of government. It does not seem to me that debate, however robust, needs to descend to public acts which incite hatred, serious contempt or severe ridicule of a particular group of persons. Further, to the extent that what is recognised as legitimate political debate would fall within s 49ZT the exemption in s 49ZT(2)(c) in my opinion provides adequate protection. In those circumstances the legislation provides the appropriate balance between the legitimate end of preventing homosexual vilification and the requirement of freedom to discuss and debate government or political matters, required by the Constitution.

In the Queensland case Owen v Menzies, the court also considered whether s 124A of the Queensland Anti-Discrimination Act was inconsistent with the implied constitutional freedom of political communication. ${ }^{38}$ The respondent had published material such as "the only rights gays have is the right to die." ${ }^{, 39} \mathrm{He}$ argued "s 124A is either wholly invalid or should be read down to exclude conduct such as [his own] which is protected by the implied constitutional freedom of political communication." 40 After considering the scheme and purpose of the Act, the Court found that ss $124 \mathrm{~A}(1)$ and (2), read together, did not burden the freedom of political communication - the first part of the Lange test. ${ }^{41}$ Rather, the court considered that: ${ }^{42}$

\footnotetext{
${ }^{35}$ At [47], referring to Australian Capital Television Pty Ltd v Commonwealth supra at 169.

${ }^{36}$ At [48].

${ }^{37}$ At [52].

${ }^{38}$ Owen $v$ Menzies, above n 29, at [61].

${ }^{39}$ At [23].

${ }^{40}$ At [69].

${ }^{41}$ At [72].

${ }^{42}$ At [72]-[73].
} 
[T] he terms of $\mathrm{s} 124 \mathrm{~A}$ set parameters to enhance communications about government and political matters in a civilised, diverse democracy which values all its members, irrespective of race, religion, sexuality or gender identity.

It is true, as Mr Owen submits, that insult and invective can be legitimate forms of political communication protected by the implied freedom. But simply because a statement contains insult and invective does not mean it relates to government or political matters. Insult and invective can be an effective form of legitimate political and government communication without, in the terms of s $124 \mathrm{~A}$, inciting hatred towards, serious contempt for, or severe ridicule of others on the ground of their race, religion, sexuality or gender identity. I cannot see that the incitement of hatred towards, serious contempt for, or severe ridicule of others on the grounds of race, religion, sexuality or gender can amount to political and government communication of the kind contemplated by the implied freedom under a diverse, modern democracy.

The court recognised that this approach was in conflict with that taken by the NSW court in Sunol (No 2) but noted that its decision did reflect the minority view of Basten JA in that case. ${ }^{43}$ Although it answered in the negative to the first prong of the Lange test, it went on to shortly consider the second question, finding "no doubt" that the provision was reasonably appropriate and served a legitimate end, that end being: ${ }^{44}$

[T] he promotion of equality of opportunity for all members of the community by prohibiting objectionable conduct inconsistent with the purposes of the Act and the Queensland Parliament's desire to improve the quality of democratic life through an educated community appreciative and respectful of the dignity and worth of all its members.

It thus seems clear that in both NSW and Queensland, 'hate speech' anti-vilification legislation is considered to either not burden the implied constitutional freedom of political communication, or to create a burden which is nevertheless justified as reasonably appropriate and serving a legitimate end. This is especially true given the exceptions allowed for in both sets of legislation.

\section{$2 \quad$ Canada}

Like Australia, Canada has both federal and provincial legislation covering hate speech. Canada does however have federal human rights legislation - the Canadian Charter of

\footnotetext{
${ }^{43}$ At [76].

${ }^{44}$ At [77].
} 
Rights and Freedoms, ${ }^{45}$ which forms part of the Canadian Constitution, and the Canadian Human Rights Act. ${ }^{46}$ The Charter grants freedom of expression ${ }^{47}$ as well as the right to equality and non-discrimination. ${ }^{48}$ The Human Rights Act is aimed at "extending the laws ... that proscribe discrimination" 49 , and somewhat controversially included a section on "hate messages". 50 This section made it a "discriminatory practice" to communicate, by telephone or (later) by internet: ${ }^{51}$

[A]ny matter that is likely to expose a person or persons to hatred or contempt by reason of the fact that that person or those persons are identifiable on the basis of a prohibited ground of discrimination.

This was challenged as unconstitutional in that it contravened the Charter right to freedom of expression, but the Supreme Court of Canada in a 4-3 decision held that it was constitutional and a reasonable limit on freedom of expression. ${ }^{52}$

This was again challenged in a recent case decided first by the Canadian Human Rights Tribunal and then by the Canadian Federal Court. The Human Rights Tribunal, in Warman $v$ Lemire, refused to apply s 13(1) on the grounds that the restrictions imposed were inconsistent with s 2(b) of the Charter. ${ }^{53}$ In 1998 and 2001 the Canadian Parliament had enacted amendments to the Human Rights Act, which gave the Tribunal additional remedial powers including granting compensation and ordering penalties ${ }^{54}$ and included computer or internet communications in the scope of $\mathrm{s} 13(1) .{ }^{55}$ The Tribunal, taking these changes into account, considered that the modifications of the $\mathrm{s} 13$ regime allowed it to revisit the question of justification, ${ }^{56}$ that the case was now distinguishable from Taylor, and that s 13 in conjunction with the penalty provisions was now inconsistent with the Charter. As a result the Tribunal declined to apply either s 13 or the penalty provisions.

\footnotetext{
${ }^{45}$ Constitution Act 1982 (Canada), Part I, Canadian Charter of Rights and Freedoms.

${ }^{46}$ Canadian Human Rights Act (Canada), RSC 1985, c H-6.

${ }^{47}$ Charter of Rights and Freedoms, above n 45, s 2(b).

${ }^{48}$ Section 15.

${ }^{49}$ Canadian Human Rights Act, above n 46.

${ }^{50}$ Section 13.

${ }^{51}$ Section 13(1), (2).

${ }^{52}$ Canada (Human Rights Commission) v Taylor [1990] 3 SCR 892.

${ }^{53}$ Canadian Human Rights Commission v Warman (2012) FC 1162.

${ }^{54}$ At [19]-[20]. See Canadian Human Rights Act ss 53(2)(e), 53(3), 54(1)(b), 54(1)(c).

${ }^{55}$ At [21]. See Canadian Human Rights Act s 13(2).

${ }^{56}$ At [28].
} 
The Federal Court overturned this decision, reverting to the Supreme Court's decision in Taylor and finding s 13(1) constitutional. However it too found that the penalty provisions were not justifiable under s 1 of the Charter and declared them of no force or effect. ${ }^{57}$ It noted that any consideration of the constitutionality of s 13 must be left to the Supreme Court of Canada.

In a more recent development s 13 was repealed by a private member's Bill that received assent on 26 June 2013, although the repeal will not take effect until $2014 .{ }^{58}$ At a federal level, hate speech is now governed only by s 319 of the Canadian Criminal Code. This section makes hate speech an indictable offence, but the requirements of the statute are far more limited and require incitement of hatred that is likely to lead to a breach of the peace. ${ }^{59}$

Although hate speech is now less covered in Canadian federal law, various Canadian provinces continue to address hate speech in their provincial legislation. Since Warman was decided, the Supreme Court has returned its decision in Whatcott. ${ }^{60} \mathrm{Mr}$ Whatcott had distributed flyers that were alleged to promote hatred against individuals on the basis of sexual orientation. Section 14(1)(b) of the Saskatchewan Human Rights Code provides that: ${ }^{61}$

No person shall publish or display... any representation ... that exposes or tends to expose to hatred, ridicules, belittles or otherwise affronts the dignity of any person or any class of persons on the basis of a prohibited ground.

The Supreme Court considered the constitutionality of s 14(1)(b), finding that it did breach freedom of expression but that it could be saved by $\mathrm{s} 1$ of the Charter. This section operates as a limiting section equivalent to $\mathrm{s} 5$ of the New Zealand Bill of Rights Act. The test applied was that laid out in Oakes: ${ }^{62}$

1) is the objective of the limit pressing and substantial;

2) whether the provision is proportionate;

a) is the limit rationally connected to its objective?

b) Does the limit minimally impair the right or freedom?

\footnotetext{
${ }^{57}$ At [17].

${ }^{58}$ Statutes of Canada 2013, Chapter 37, Bill C-304 (An Act to amend the Canadian Human Rights Act (protecting freedom)).

${ }^{59}$ Canadian Criminal Code (Canada), s 319.

${ }^{60}$ Whatcott $v$ Saskatchewan Human Rights Tribunal (2013) SCC 11.

${ }^{61}$ Saskatchewan Human Rights Code (Canada), s 14(1)(b).

${ }^{62}$ R. v Oakes [1986] 1 SCR 103.
} 
The Court had "no difficulty" in finding the objective pressing and substantial. ${ }^{63}$ In considering proportionality, they first established that: ${ }^{64}$

A prohibition of hate speech will only be rationally connected to the objective if its ambit is limited to expression publicly directed at a protected group, or at an individual on the basis that he or she is a member of that group.

The Court discussed the inclusion of "ridicules, belittles, or affronts the dignity of" in $\mathrm{s}$ 14(1)(b), as these words had been claimed to widen the ambit of the hate speech provision 'to capture 'hurt feelings' and 'affronts to dignity' that are not tied to the objective of eliminating discrimination." 65 The Court found that the Saskatchewan Court of Appeal had, both prior to and after the ruling in Taylor, applied the provision narrowly, "essentially ... ignor[ing]" the more expansive wording. ${ }^{66}$ Nevertheless, it recognised that without an express declaration of invalidity, these words might have a chilling effect on expression. ${ }^{67}$ The Court found that the wording was not rationally connected to its objective and was therefore constitutionally invalid, so severed the words from the rest of the provision and formally struck them from the section. ${ }^{68}$ After considering whether the remainder of the provision minimally impaired freedom of expression - taking into account the wording of the section, the nature of the expression affected, the place of political discourse, sexual orientation versus behaviour, intent, proof, and defences - the Court concluded that the section met the minimal impairment requirement, and thus: ${ }^{69}$

The limitation imposed on freedom of expression by the prohibition in s. 14(1)(b) of the Code, when properly defined and understood, is demonstrably justified in a free and democratic society.

As the Court explained, a hate speech case involves: ${ }^{70}$

[B]alanc[ing] fundamental values underlying freedom of expression ... in the context in which they are invoked, with competing Charter rights and other values essential to a free and democratic society, in this case, a commitment to equality and respect for group identity and the inherent dignity owed to all human beings.

\footnotetext{
${ }^{63}$ Whatcott $v$ Saskatchewan Human Rights Tribunal, above n 60, at [77].

${ }^{64}$ At [84].

${ }^{65}$ At [85].

${ }^{66}$ At [88].

${ }^{67}$ Above.

${ }^{68}$ At [92]-[94].

${ }^{69}$ At [151].

${ }^{70}$ At [66].
} 
Whatcott illustrates that carefully worded provisions which take a restrictive interpretation toward the meaning of 'hate speech', while still infringing upon an absolute freedom of expression, can be justified constitutionally.

\section{$3 \quad$ South Africa}

South Africa's Constitution entrenches freedom of expression under s 16, but makes explicitly clear in s 16(2)(c) that the right "does not extend to advocacy of hatred that is based on race, ethnicity, gender or religion, and that constitutes incitement to cause harm." The Promotion of Equality and Prevention of Unfair Discrimination Act 4 of 2000, known as the Equality Act, prohibits hate speech: ${ }^{71}$

10(1) Subject to the proviso in section 12 no person may publish, propagate, advocate or communicate words based on one or more of the prohibited grounds against any person that could reasonably be construed to demonstrate a clear intention to-
(a) Be hurtful;
(b) Be harmful or to incite harm;
(c) Promote or propagate hatred.

These prohibited grounds are both listed and unlisted, the latter being grounds which "perpetuate systemic disadvantage or loss of dignity or which affect a person in the same way as listed grounds."72 In a 2010 case, the Equality Court found that public speech which perpetuates rape myths is hate speech against women. ${ }^{73}$ In that case, the respondent had made a public speech with regard to an earlier rape trial, $S v$ Zuma, stating that: ${ }^{74}$

When a woman didn't enjoy it, she leaves early in the morning. Those who had a nice time will wait until the sun comes out, request breakfast and taxi money. In the morning that lady requested breakfast and taxi money. You don't ask for taxi money from somebody who raped you.

\footnotetext{
${ }^{71}$ Promotion of Equality and Prevention of Unfair Discrimination Act 2000 (South Africa), s 10.

${ }^{72}$ Sonke Gender Justice Network v Malema (2010) (7) BCLR 729 (EqC) at [11]. The complainant in the case, SONKE Gender Justice Network, is a non-profit organisation which works to "promote gender equality, prevent domestic and sexual violence, and reduce the spread and impact of HIV and AIDS." $<$ http://genderjustice.org.za $>$.

${ }^{73}$ Sonke Gender Justice Network v Malema, above.

${ }^{74}$ At [2].
} 
The court heard evidence from an expert in the field of gender violence, who testified that the comment had distorted the actual findings of the case and created a myth regarding how women are expected to behave in the aftermath of a rape: ${ }^{75}$

The comments made ... rely upon generalisations about women, rape and consent which reinforce rape myths and that [the respondent] is abrogating to himself the prerogative of deciding what does and does not constitute rape. Myths and stereotypes are typically created by groups dominant in society. Thus, when men proclaim what is and is not sexual violence, and justify their reasoning with rape myths, they reinforce men's dominance and perspectives at the expense of women's equality.

The Court found that "the uttered words could reasonably be construed as hurtful, harmful and demeaning to women" and therefore amounted to hate speech, and could not be excluded under s 12, which created a defence of 'fair comment'.

This case illustrates how what may not be conceived of as 'hate speech' can nevertheless fall within hate speech provisions. South African courts may be more likely to view public speech perpetuating rape myths as hate speech due to the extremely high rates of sexual assault in South Africa. ${ }^{76}$ The complainant made clear that the speech was considered "gender insensitive, more so in the light that South Africa has a high statistic of rape."77 A legal form of challenging the way people, especially public figures, comment publicly about rape and sexual assault may be useful in addressing attitudes that contribute to such high statistics.

\section{$4 \quad$ United Kingdom}

The United Kingdom has extensive legislation covering what might be termed as 'hate speech', though none of it is framed within an anti-discrimination legislation framework as in other jurisdictions discussed, and none of it specifically relates to hate speech against gender and sexual minorities. The most far-reaching provisions are sections 4A and 5 of the Public Order Act 1986, which respectively prohibit using or displaying threatening, abusive or insulting words with intent to cause harassment, alarm, or distress (and thereby causing that harassment, alarm, or distress), ${ }^{78}$ and using or displaying threatening, abusive or insulting words "within the hearing or sight of a

\footnotetext{
${ }^{75}$ At [19].

${ }^{76}$ Statistics South Africa Quantitative Research Findings on Rape in South Africa (2000) $<$ http://www.statssa.gov.za>.

${ }^{77}$ Sonke Gender Justice Network v Malema, above n 72, at [17](b)(iii).

78 Public Order Act 1986 (United Kingdom), s 4A.
} 
person likely to be caused harassment, alarm or distress thereby". ${ }^{79}$ The Public Order Act also includes more specific provisions regarding racial hatred.

The United Kingdom has a Human Rights Act which grants its citizens certain rights and freedoms including freedom of expression: ${ }^{80}$

Everyone has the right to freedom of expression. This right shall include freedom to hold opinions and to receive and impart information and ideas without interference by public authority and regardless of frontiers. This Article shall not prevent States from requiring the licensing of broadcasting, television or cinema enterprises.

However, this right is expressly limited in a number of ways: ${ }^{81}$

The exercise of these freedoms, since it carries with it duties and responsibilities, may be subject to such formalities, conditions, restrictions or penalties as are prescribed by law and are necessary in a democratic society, in the interests of national security, territorial integrity or public safety, for the prevention of disorder or crime, for the protection of health or morals, for the protection of the reputation or rights of others, for preventing the disclosure of information received in confidence, or for maintaining the authority and impartiality of the judiciary.

These extensive limitations mean that the Public Order Act can likely be justified "for the prevention of disorder or crime", but they would also protect hate speech legislation created within an anti-discrimination context. More specific hate speech legislation would offer better protection for gender and sexual minorities, and better clarification of the law for those required to apply it. There have been multiple incidents of evangelical Christians handing out homophobic leaflets being arrested under s 4A and 5 of the Public Order Act, but all cases have resulted in charges being dropped. ${ }^{82}$ In contrast, s 5 often features in cases involving 'football hooliganism', indicating that the existing provisions are not enforced to punish hate speech or protect minorities but to deter public disorder and rioting. ${ }^{83}$

Any new hate speech provision predicated on the same "harassment, alarm, or distress" requirement as s 5, however, would likely fail on questions of balancing against the

\footnotetext{
79 Section 5.

${ }^{80}$ Human Rights Act 1998 (United Kingdom), Schedule I, Article 10(1).

${ }^{81}$ Article 10(2).

${ }^{82}$ See for example "Anti-gay leaflets charge dropped" (28 September 2006) BBC News UK

$<$ http://news.bbc.co.uk/2/hi/uk_news/wales/5388626.stm>.

${ }^{83}$ See for example $R v$ O'Keefe [2003] All ER (D) 81 (Sep).
} 
freedom of expression. Hate speech must go further than hurt feelings or offence. Equally, alarm and distress are not sufficient to justify banning types of expression.

\section{$5 \quad$ United States}

Unlike other jurisdictions mentioned here, the United States First Amendment grants a near-absolute freedom of speech which is not balanced against other rights and freedoms as part of an overall constitutional/rights framework. While some limitations have been successful, hate speech legislation has not been considered constitutionally valid. In the Skokie case, American Nazis planned a rally march through Skokie, largely settled by Jewish Holocaust survivors. ${ }^{84}$ The town sought an injunction against the Nazis, but this was reversed by the United States Supreme Court on the basis that the injunction preventing wearing swastikas and distributing "materials which incite or promote hatred against persons of Jewish faith or ancestry" was an infringement of the group's First Amendment rights.

Similarly, an ordinance which made it a disorderly conduct misdemeanour to display a symbol or graffiti "which one knows or has reasonable grounds to know arouses anger, alarm or resentment in others on the basis of race, color, creed, religion or gender" was struck down by the United States Supreme Court as "facially unconstitutional in that it prohibits otherwise permitted speech solely on the basis of the subjects the speech addresses. ${ }^{\prime 85}$ The Court considered content-based regulation and found that while it is not absolute, ${ }^{86}$ "the ordinance goes even beyond mere content discrimination, to actual viewpoint discrimination" 87 and that it "comes within neither any of the specific exceptions to the First Amendment prohibition ... nor a more general exception for content discrimination that does not threaten censorship of ideas." ordinance being intended to protect vulnerable minority groups, ${ }^{89}$ it could not be justified within the context of First Amendment requirements.

\section{Justifying Hate Speech Censorship}

While examining various hate speech provisions makes clear that many jurisdictions do censor hate speech, it does not necessarily explain why hate speech ought to be

\footnotetext{
${ }^{84}$ National Socialist Party of America v Village of Skokie 432 US 43 (1977).

${ }^{85}$ RAV v City of St Paul 505 US 377 (1992) at 381.

${ }^{86}$ At 387.

${ }^{87}$ At 391.

${ }^{88}$ At 393.

${ }^{89}$ At 394.
} 
censored. A range of justifications for censorship can be found both in academic writing and in judicial cases.

\section{$1 \quad$ Discrimination}

In evaluating hate speech legislation, many courts characterise the balancing act as one between the freedom of expression claimed by one citizen, and the freedom from discrimination claimed by another. This is because, as the Supreme Court recognised in Whatcott: $:^{90}$

Hate speech is, at its core, an effort to marginalize individuals based on their membership in a group. Using expression that exposes the group to hatred, hate speech seeks to delegitimize group members in the eyes of the majority, reducing their social standing and acceptance within society.

... Hate speech, therefore, rises beyond causing emotional distress to individual group members. It can have a societal impact. If a group of people are considered inferior, sub-human, or lawless, it is easier to justify denying the group and its members equal rights or status.

The Court extrapolated this "societal impact" of hate speech to identify that "[i]f a group of people are considered inferior, sub-human, or lawless, it is easier to justify denying the group and its members equal rights or status."

Both Jeremy Waldron and Ishani Maitra discuss how a lack of governmental response to hate speech can be seen as eroding social assurance or granting authority to hate speakers. Waldron argues that the point of hate speech is not just for hate speakers to let off steam, but to "target [and] negate the implicit assurance that a society offers to the members of vulnerable groups." 92 If the state does not challenge such hate speech, it not only risks harm to minorities, it risks the establishment of "a rival public good" that undermines the "public good of implicit assurance" and indicates to others that they are not alone in their bigotry. ${ }^{93}$

Maitra observes that where "those who do have basic authority, and thus are in a position to criticise or otherwise disavow [the hate speaker's] actions, clearly and

\footnotetext{
${ }^{90}$ Whatcott v Saskatchewan Human Rights Commission, above n 60, at [71], [74].

${ }^{91}$ At [74].

92 Jeremy Waldron The Harm in Hate Speech (Harvard University Press, Cambridge, Massachusetts, 2012) at 88 .

${ }^{93}$ At $94-95$.
} 
markedly fail to do so ... this omission confers derived authority."94 This derived authority then grants the hate speakers the ability to perform what he describes as "authoritative illocutions", a type of speech that constitutes subordination and constructs a social reality for the subordinated minority. ${ }^{95}$ Maitra therefore contends that permitting hate speech creates tacit approval for those seeking to marginalise minorities and to discriminate against them in more overt ways.

\section{$2 \quad$ Denying speech}

Another argument against hate speech is that by subordinating and attacking minorities, it also attacks their ability to engage in speech of their own. The Court in Whatcott identified a particular way in which hate speech denies minorities full and equal participation in any public debate: ${ }^{96}$

Hate speech is not only used to justify restrictions or attacks on the rights of protected groups on prohibited grounds.... [H]ate propaganda opposes the targeted group's ability to find self-fulfillment by articulating their thoughts and ideas. It impacts on that group's ability to respond to the substantive ideas under debate, thereby placing a serious barrier to their full participation in our democracy. Indeed, a particularly insidious aspect of hate speech is that it acts to cut off any path of reply by the group under attack. It does this not only by attempting to marginalize the group so that their reply will be ignored: it also forces the group to argue for their basic humanity or social standing, as a precondition to participating in the deliberative aspects of our democracy.

... In this way, the expression inhibits the protected group from interacting and participating in free expression and public debate.

Caroline West makes a similar argument cast in a different light. She refers to two related concepts, comprehension failure and consideration failure, and the way in which both concepts are affected and reinforced by hate speech. ${ }^{97}$ The former involves a belief in audiences that a particular class of people are "by nature intellectually simple, incapable of complex or fully rational thought", a belief which if reinforced by hate speech will have the effect of "preventing [minorities] from communicating all but the most simple opinions." $" 98$ The latter, consideration failure, may be more prevalent in the

\footnotetext{
${ }^{94}$ Ishani Maitra "Subordinating Speech" in Ishani Maitra and Mary Kate McGowan Speech and Harm: Controversies over Free Speech (Oxford University Press, Oxford, 2012) 94 at 110. 
case of hate speech against gender and sexual minorities: it exists where: "the audience grasps what the speaker means to say perfectly well, but ignores it or dismisses it ... because they believe the speaker is not the kind of person worth listening to." 99 West argues that "there is considerable evidence that ... hate speech ... functions to undermine the attention and consideration that is paid to the speech of those it targets. ${ }^{100}$ She further states that: ${ }^{101}$

[C]onsideration failure can here form part of a self-reinforcing cycle of marginalization. ... This cycle must somehow be interrupted if members of historically marginalized groups are to have a reasonable chance of reshaping the moral and political environment through speech.

Thus hate speech can in multiple ways be seen as attacking minorities' ability to communicate and engage in equal participation within society and societal discussion.

\section{$3 \quad$ Harm}

Proponents of anti-hate speech legislation often argue that hate speech goes further than offensiveness; it is a type of harm. Waldron makes clear that this harm should be considered in the context of its victims, the vulnerable members of society; "[i]t is not harm - if I can put it bluntly - to the white liberals who find the racist invective distasteful." "102 As Asaf Fisher recognises, "[i]t causes injury. It is the verbal equivalent of a "slap in the face." 103 Anne Scahill, in a consideration of the NSW homosexual vilification legislation, refers to Joel Bakan's analysis of harm in relation to pornography, which she sees as "an interesting framework which may be utilised in examining the concept of harm in the vilification debate."104 Bakan outlines two bases of justification for the suppression of pornography: ${ }^{105}$

1. The direct harm basis; pornography causes direct psychological harm to women as it diminishes women's dignity and thereby causes hurt. There are many examples of the recognition of psychological harm in the law, including assault which may be occasioned by words, for example by defamation or sexual harassment.

\footnotetext{
${ }^{99}$ Above.

${ }^{100}$ Above.

${ }^{101}$ At 245.

102 Waldron, above n 92, at 33.

${ }^{103}$ Asaf Fisher "Regulating Hate Speech" (2006) 8 UTS L Rev 21 at 29.

${ }^{104}$ Anne Scahill “Can Hate Speech Be Free Speech?” (1994) 4 Australasian Gay \& Lesbian LJ 1 at 20.

105 At 20, quoting Joel Bakan "Pornography, Law and Moral Theory” (1985) 17 Ottawa L R 1.
} 
2. The provocation basis; pornography provokes men to behave in a way that causes direct harm to women either through violence or discrimination.

These two bases can be used similarly to examine harm in hate speech. Scahill identifies that: ${ }^{106}$

As many societal attitudes may direct that the loss of homosexual dignity is regarded as a poor justification for interference with freedom of expression; advocates of homosexual vilification legislation are more likely to rely on the provocation thesis; arguing that negative public statements about homosexual men incite hatred, discrimination and violence against them.

In another evaluation of the NSW measures, Ryan Takach details the actual violence directed against sexual minorities, finding that " $[\mathrm{t}]$ he Bill was unarguably prompted by the high level of violence directed against gay men and lesbian women because of their homosexuality." " He refers to multiple research initiatives that have "documented the nature and extent of such violence" 108 , including 'gay hate' murders, physical injury and verbal assault. Takach found that "[i]n light of the survey findings, language is seen to play a major role in violence against lesbians and gay men." 109 On the basis of such findings, supporters of hate speech legislation argue that: ${ }^{110}$

[V]iolence and crimes against lesbian and gay citizens have real and tangible links to daily behaviour as a result of the messages which are imprinted in the cultural psyche by such language.

Despite these links between hate speech and violence, some opponents argue against justifying hate speech legislation based on only a 'risk' of harm. The Court in Whatcott found that: ${ }^{111}$

Such an approach, however, ignores the particularly insidious nature of hate speech. The end goal of hate speech is to shift the environment from one where harm against vulnerable groups is not tolerated to one where hate speech has created a place where this is either accepted or a blind eye is turned.

The Court similarly recognised that: ${ }^{12}$

\footnotetext{
${ }^{106}$ At 21 .

${ }^{107}$ Ryan Takach "Gay and Lesbian Inequality: The Anti-Vilification Measures” (1994) 4 Australasian Gay \& Lesbian LJ 30 at 30.

${ }^{108}$ At 321.

${ }^{109}$ At 33

${ }^{110}$ At 34.

${ }^{111}$ Whatcott v Saskatchewan Human Rights Commission, above n 60, at [131].
} 
As the majority becomes desensitized by the effects of hate speech, the concern is that some members of society will demonstrate their rejection of the vulnerable group through conduct. Hate speech lays the groundwork for later, broad attacks on vulnerable groups. These attacks can range from discrimination, to ostracism, segregation, deportation, violence and, in the most extreme cases, to genocide (see Taylor and Keegstra).

It seems relatively clear that hate speech legislation can be justified at the very least through demonstration of Bakan's 'provocation' concept. While Scahill might be correct in finding that societal attitudes tend to disregard the diminishment of dignity as a valid harm that justifies censorship, various legal theorists have developed the concept into one which may be considered separately to 'harm'.

\section{$4 \quad$ Denying dignity and assurance}

Waldron uses 'dignity' as a catch-all term to describe a person's basic social standing and assurance, the right to be treated "as proper objects of society's protection and concern", and the "fundamentals of basic reputation that entitle them to be treated as equals in the ordinary operations of society." ${ }^{113}$ He argues that: ${ }^{114}$

[T] he publication of hate speech is calculated to undermine this [and] compromise the dignity of those at whom it is targeted, both in their own eyes and in the eyes of other members of society.

The point of hate speech legislation, in this conception, is that dignity "as a society and legal status ... has to be established, upheld, maintained, and vindicated by society and the law." 115

\section{Defining Hate Speech}

Considering the various definitions of 'hate speech' across jurisdictions, it seems clear that a unified conception of hate speech could assist with avoiding overreaching into the realm of free expression. The more carefully and narrowly 'hate speech' is defined, the less likely it is to impair this freedom, while still achieving its purpose in protecting vulnerable groups and individuals within society. That Canada recently repealed its federal hate speech provision indicates that even jurisdictions which are generally

\footnotetext{
${ }^{112}$ At [74].

${ }^{113}$ Waldron, above $\mathrm{n} 92$, at 5 .

${ }^{114}$ Above.

${ }^{115}$ At 60.
} 
comfortable with censoring some expression are cautious about overly-broad hate speech legislation. Any legislation which strikes at free expression ought to be relatively focussed in scope, so as to not catch too much speech in its net.

Definitions of hate speech tend to fall at various points on a spectrum where one end involves only the most egregious examples - speech which actively and intentionally incites hatred, violence and abuse. The other end of the spectrum includes speech that is hurtful, offensive or distressing, but which does not necessarily convey hatred or serious contempt.

Vilification, as defined in Australia, does appear to involve abuse and hatred. Certainly, the NSW legislature and courts have turned away from a lower level definition. The legislation requires that hate speech must 'incite hatred towards, serious contempt for, or severe ridicule of, a person or group of persons.' The Court in Sunol v Collier ruled that: ${ }^{116}$

[S]atisfaction of s 49ZT(1) is not necessarily to be assumed or concluded by rude, indecorous, base or insulting language that reflects some dislike of, or opposition to, homosexuality. The section provides for an act to incite hatred, serious contempt, or severe ridicule. Fine linguistic distinctions should of course not be drawn which may deflect attention from the language of the statute. The words of the statute are to be applied with a recognition of the degree or quality of the act contemplated by the language. The act is to be assessed by reference to the context in which it takes place, including the audience or likely audience.

As recognised by anti-discrimination authors in Australia, legislation following the "NSW model" has given rise to "a number of issues concerning the interpretation of this element of the civil wrong."117 These issues were considered in Veloskey $v$ Karagiannakis, and the outcome was summarised by the Court in Barry v Futter: ${ }^{118}$

(a) The word 'incite' in this context has its ordinary English meaning, namely, to urge, spur on, stir up, animate, stimulate or prompt to action;

(b) It is not sufficient if words merely convey hatred or express serious contempt or severe ridicule;

\footnotetext{
${ }^{116}$ Sunol v Collier (No 2), above n 33, at [62].

${ }^{117}$ Neil Rees, Katherine Lindsay and Simon Rice Australian Anti-Discrimination Law: Texts, Cases and Materials (Federation Press, Annandale, New South Wales, 2008) at 582.

${ }^{118}$ Barry v Futter, above n 20, at [81], referring to Veloskey v Karagiannakis [2002] NSWADTAP 18 at [21], [24], [25], [26], [28].
} 
(c) Section $38 \mathrm{~S}$ does not require any intention to incite on the part of the respondent to the complaint, nor is it necessary that the complainant prove that anyone was actually incited by the public act to respond in the requisite manner;

(d) What is required is that the public act is capable, in an objective sense, of inciting others to feel hatred towards or serious contempt for, or severe ridicule of a person or persons on the [protected ground];

(e) The question therefore to be addressed is could the ordinary, reasonable hearer understand from the public act that he or she is being incited to hatred towards or serious contempt for, or severe ridicule of a person or persons on the [protected ground]? The question is not, could the ordinary reasonable reader reach such a conclusion after his/her own beliefs have been brought into play by the public act?

As a result, it is clear that legislation based on the NSW model is near the top end of the spectrum, although it does not require actual intention on the part of the speaker or actual incitement on the part of the audience.

In the Canadian context, the court in Taylor found that: ${ }^{19}$

The terms of the section, in particular the phrase 'hatred or contempt', are sufficiently precise and narrow to limit its impact to those expressive activities which are repugnant to Parliament's objective of promoting equality and tolerance in society. That no special provision exists to emphasize the importance of minimally impairing the freedom of expression does not create in s 13(1) an overly wide or loose scope, for both its purpose and the common law's traditional desire to protect expressive activity permit an interpretation solicitous of this important freedom.

The Court of Appeal in Warman referred to "more precise guidelines as to what constitutes hate speech" which had been laid down by the Canadian Tribunal in Warman $v$ Kouba. ${ }^{120}$ It established these as follows: ${ }^{121}$

(a) The targeted group is portrayed as a powerful menace that is taking control of the major institutions in society and depriving others of their livelihoods, safety, freedom of speech and general well-being;

\footnotetext{
${ }^{119}$ Canada (Human Rights Commission) v Taylor, above n 52, at [81].

${ }^{120}$ Canada (Human Rights Commission) v Warman, above n 53, at [124], referring to Warman v Kouba (2006) CHRT 50 at 24-81.

${ }^{121}$ Canada (Human Rights Commission) $v$ Warman at [124].
} 
(b) The messages use "true stories", news reports, pictures and references from purportedly reputable sources to make negative generalizations about the targeted group;

(c) The targeted group is portrayed as preying upon children, the aged, the vulnerable, etc.;

(d) The targeted group is blamed for the current problems in society and the world;

(e) The targeted group is portrayed as dangerous or violent by nature;

(f) The messages convey the idea that members of the targeted group are devoid of any redeeming qualities and are innately evil;

(g) The messages communicate the idea that nothing but the banishment, segregation or eradication of this group of people will save others from the harm being done by this group;

(h) The targeted group is de-humanized through comparisons to and associations with animals, vermin, excrement, and other noxious substances;

(i) Highly inflammatory and derogatory language is used in the messages to create a tone of extreme hatred and contempt;

(j) The messages trivialize or celebrate past persecution or tragedy involving members of the targeted group; and

(k) The messages contain calls to take violent action against the targeted group.

As the Court recognised, "[t]hese 'hallmarks' of hate speech can not be characterized as vague and imprecise." 122 Rather, they create specific benchmarks against which any potential hate speech can be applied. They also illustrate that one can engage in contentious debate, and even criticise minority groups, without attacking them in a way that exposes them to hatred and harm.

Canada differs from the NSW Australian model in that it does not include 'ridicule'. However, NSW courts made clear that only 'severe ridicule' was to be included. As identified in Whatcott, severe ridicule may go beyond humour and expose the target to hatred. ${ }^{123}$ While the Court in Whatcott chose to remove ridicule from the wording of the Saskatchewan hate speech provision, on the basis that "the risk results from the intensity of the ridicule reaching a level where the target becomes exposed to hatred" rather than the ridicule itself, it does not seem that including severe ridicule will in practice censor much more expression than is already caught. ${ }^{124}$

It is clear that the South African concept of hate speech is far broader and toward the lower end of the spectrum. The court in Sonke Justice v Malema recognised that: ${ }^{125}$

\footnotetext{
${ }^{122}$ At [125].

${ }^{123}$ Whatcott $v$ Saskatchewan Human Rights Commission, above n 60, at [91].

${ }^{124}$ At [91].

125 Sonke Gender Justice Network v Malema, above n 72, at [13].
} 
[I]t is clear that the Equality Act's definition of hate speech is broad. It extends beyond communicated words that promote hatred by specifically including within its scope the communication of words that are hurtful or harmful.

Hurt or harm in this context is not limited to direct physical harm, and extends to an attack on dignity.

Comparing this definition with that discussed in Whatcott, the Canadian courts have taken a far more restrictive stance. Canadian courts "have generally identified only extreme and egregious examples of delegitimizing expression as hate speech. This approach excludes merely offensive or hurtful expression from the ambit of the provision." ${ }^{126}$ In the context of a Bill of Rights or Charter such as New Zealand's or Canada's, neither of which includes an express limitation on freedom of expression as the South African Constitution does, the broad concept of hate speech does not seem appropriate. That said, it may be that the South African Equality Act's use of 'hurtful or harmful' does not refer so much to 'hurt feelings' as to the kind of societal harm and denial of dignity discussed as potential justifications above. This interpretation would bring the South African concept of hate speech more in line with the others discussed.

\section{Legislating Against Hate Speech in New Zealand}

\section{A Existing Censorship in New Zealand}

New Zealand is, to some extent, fundamentally comfortable with the concept of censoring certain types of expression. Censorship in New Zealand tends to be predicated on a basis of harm or injury to the public good.

$1 \quad$ Films, Videos, and Publications Classification Act 1993 and the Office of Film and Literature

The Films, Videos, and Publications Classification Act 1993 (FVPCA) both requires and allows for the classification of various material as "objectionable", defined as material which "describes, depicts, expresses or otherwise deals with matters such as sex, horror, crime, cruelty, or violence in such a manner that the availability of the publication is likely to be injurious to the public good." 127

\footnotetext{
${ }^{126}$ Whatcott $v$ Saskatchewan Human Rights Commission, above n 60, at [46].

${ }^{127}$ Films, Videos, and Publications Classification Act 1993, s 3(1).
} 
This classification is carried out by the Office of Film and Literature (OFLC) and is based on various criteria, including: ${ }^{128}$

[T] he extent and degree to which, and the manner in which, the publication represents (whether directly or by implication) that members of any particular class of the public are inherently inferior to other members of the public by reason of any characteristic of members of that class, being a characteristic that is a prohibited ground of discrimination specified in section 21(1) of the Human Rights Act 1993.

On the face of this section, it appears that the OFLC has the power to censor material that could be considered hate speech. However, case law has narrowed the application of $\mathrm{s} 3$, and as a result, the OFLC is limited in what it can legally censor.

\section{$2 \quad$ Limitations on OFLC power}

The OFLC is limited by a "subject matter gateway". This is the requirement of s 3(1) that the material "deal with matters such as sex, horror, crime, cruelty, or violence". In Living Word, involving videos which opposed granting rights to gay people and which had been classified as 'objectionable' under s 3(3)(e), the Court of Appeal considered this subject matter gateway and found that: ${ }^{129}$

The words used in s 3 limit the qualifying publications to those that can fairly be described as dealing with the matters of the kinds listed. ... The collocation of words "sex, horror, crime, cruelty or violence", as the matters dealt with, tends to point to activity rather than to the expression of opinion or attitude.

Furthermore, the Court ruled that "[i]t is therefore wrong to approach the Act as if it is directed at preventing discrimination." 130 This ruling ensured that the OFLC is limited in its censorship abilities. As the Government Administration Committee found in its Inquiry into Censorship Issues in March 2003: ${ }^{131}$

The Court of Appeal ... also held that the application of section 3(1) of the Act was restricted to those publications that described, depicted or otherwise dealt with activity of a sexual, violent, or criminal nature, rather than applying to those publications that were attempting to convey an attitude or opinion.

\footnotetext{
${ }^{128} \mathrm{~S} \mathrm{3}(3)(\mathrm{e})$.

${ }^{129}$ Living Word Distributors Ltd v Human Rights Action Group Wellington [2000] 3 NZLR 570 (CA) Richardson $\mathrm{P}$ at [28].

${ }^{130}$ Thomas J at [76].

${ }^{131}$ Government Administration Committee Inquiry into Censorship Issues (March 2003) I.5A at 15-16.
} 
... The effect of the Living Word decision has been to limit the scope of 'matters such as sex' so as not to cover sexual orientation, the sexual transmission of HIV, or the 'hate speech' related to them.

The Inquiry into Censorship Issues proposed two options for extending OFLC power relating to censorship of objectionable material; either removing the subject matter gateway, or replacing 'such as' with 'includes'. The Inquiry recognised that either option: ${ }^{132}$

[W]ould negate the need for the inclusion of a specific 'hate speech' section in the Act. If the Act is amended as we recommend, the censors would be able to address issues of this nature by application of the 'injury to the public good' test. The censorship net would be able to reach, for example, the material that vilified certain groups in the Living Word videos without the need to explicitly identify such groups in the Act. Government members find this acceptable, particularly as it will not elevate the importance of any one group over another.

Despite this recommendation, s 3(1) has not been amended to incorporate either of these options. Following the Inquiry into Censorship Issues, the Government Administration Committee initiated an Inquiry into Hate Speech in 2004. However, although submissions were made to the Inquiry, it was discharged in 2006 with no report or outcomes eventuating.

\section{B Extending Hate Speech Legislation}

\section{$1 \quad$ Proposed legislation}

After examining other types of hate speech legislation that protect gender and sexual minorities, and different conceptions of how 'hate speech' should be interpreted, I submit that it is appropriate for New Zealand to enact a provision extending protection from hate speech including the basis of gender and sexual orientation.

\section{a) Human Rights Act provisions}

I recommend that s 61 of the Human Rights Act be repealed and replaced with a new section entitled 'Hate speech'. The new section will remove the wording "words or matter which is threatening, abusive, or insulting" as well as the passage:

\footnotetext{
${ }^{132}$ At 23 .
} 
Being matter or words likely to excite hostility against or bring into contempt any group of persons in or who may be coming to New Zealand on the ground of the colour, race, or ethnic or national origins of that group of persons.

This will be replaced with the passage:

Words or matter which exposes or tends to expose to hatred or contempt any person or class of persons on the basis of their race or ethnic or national origin, religion, sexuality or gender identity.

Section 131 will be similarly amended, with the title renamed 'Inciting hatred', the words "hostility or ill-will against, or bring into contempt or ridicule" replaced with "hatred or contempt against", and the words "ground of the colour, race, or ethnic or national origins of that group of persons" amended to read "on the ground of the race or ethnic or national origin, religion, sexuality or gender identity of that group of persons".

Although this paper focuses on GSM hate speech protections, I have included race and religion as other protected groups but have not extended protection to all prohibited grounds of discrimination as established in s 21 of the Human Rights Act. This is in contrast to the choice of overseas jurisdictions such as Saskatchewan and South Africa, but other jurisdictions such as Queensland have chosen to specify grounds. The four grounds I have specified are the most likely to face hate speech given the legal and historical context, and the legislation as recommended would adequately protect the most vulnerable groups within society.

\section{b) FVPCA provisions}

The Office of Film and Literature Classification made a submission to the Inquiry into Hate Speech in October 2004 arguing that: ${ }^{133}$

If the legislature has decided that the social harm caused by hate speech is sufficient to warrant civil or criminal remedies, then the extent to which a film requiring classification is itself hate speech should logically become a matter relevant to its classification. Not to make it so would tend to undermine the purpose of legislation providing civil and criminal remedies for injury caused by hate speech, and with respect to publications requiring classification, would result in a perception of government approval of films and other publications containing hate speech.

\footnotetext{
${ }^{133}$ Office of Film and Literature Classification Submission: Inquiry into Hate Speech (29 October 2004)
} at 26 . 
I concur with this opinion. The OFLC is the relevant responsible body. It is entrusted with censoring other material on the basis of public harm. If hate speech legislation is justifiable on the basis of harm to minority groups, then it stands to reason that the OFLC should have its powers extended so that it can make decisions on the basis of hatred.

Section 3(1) could be amended to follow the recommendation of the Government Administration Committee to remove the subject matter gateway of "such as sex, horror, crime, cruelty, or violence". However, the subject matter gateway restricts the OFLC's power of censorship and to remove it would significantly expand this power beyond what was originally conceived in the legislation. The passage "matters such as sex, horror, crime, cruelty, or violence" in s 3 of the FVPCA should therefore be amended to read "matters such as sex, horror, crime, cruelty, hate speech, or violence". As the Committee recognises, "such amendment will provide a focus on the injurious to the public good' test" and would capture matters including expression classed as hate speech. ${ }^{134}$

\section{$2 \quad$ Balancing against the Bill of Rights}

Any new legislation governing hate speech would necessarily conflict with freedom of expression under the Bill of Rights Act. However, as recognised above, New Zealand does not grant freedom of expression in the same near-absolute manner as the United States First Amendment. Section 5 of the New Zealand Bill of Rights Act provides: ${ }^{135}$

Subject to section 4, the rights and freedoms contained in this Bill of Rights may be subject only to such reasonable limits prescribed by law as can be demonstrably justified in a free and democratic society.

New Zealand courts would thus be required to carry out the same determination as the Canadian Supreme Court did in Whatcott, to establish whether the limits imposed by the hate speech provision are a reasonable limit upon freedom of expression. It is partly for this reason that I have followed the Canadian model of hate speech; applying a more restrictive wording designed to catch only the most extreme types of expression will necessarily ensure that freedom of expression is subjected to a lesser limit.

Furthermore, s 6 of the Bill of Rights Act requires that: ${ }^{136}$

\footnotetext{
${ }^{134}$ Government Administration Committee Inquiry into Censorship Issues, above n 131, at 24.

${ }^{135}$ Bill of Rights Act 1990, s 5.

${ }^{136}$ Section 6.
} 
Wherever an enactment can be given a meaning that is consistent with the rights and freedoms contained in this Bill of Rights, that meaning shall be preferred to any other meaning.

This section means that New Zealand courts would strive to interpret any hate speech provision as consistently as possible with freedom of expression. In practice, this would likely mean that a restrictive interpretation to the provision would be applied.

New Zealand courts do not have the power to strike down legislation on the basis that it is inconsistent with the Bill of Rights and is not a justified limit. If New Zealand were to pass new legislation including prohibitions against ridicule or insulting language, the courts would not be able to remove those words from the provision as the Canadian Supreme Court did in Whatcott. This is another reason for any new hate speech legislation to be constructed as narrowly as possible while still protecting minority groups from vilification and exposure to hatred.

As the Government Administration Committee made clear in the Inquiry into Censorship Issues, "[c]ensorship and classification should therefore always entail a careful balancing of 'freedom of expression' and 'harm'."137 Applying a high threshold for 'hate speech' will assist with such a balancing.

\section{$3 \quad$ What might be covered?}

\section{a) Political speech}

Some 'speech' that can be seen as hate speech could be seen as deserving greater protection due to its status as 'political speech'. Mary Kate McGowan argues against this conception: ${ }^{138}$

The mere fact that an utterance expresses a political opinion cannot reasonably be treated as a sufficient condition of that utterance being political speech in the First Amendment sense ... thus, the mere fact that racist hate speech expresses a political opinion is not sufficient reason to view it as highly protected political expression.

The Supreme Court in Whatcott acknowledged that "[w]hile hate speech constitutes a type of expression that lies at the periphery of the values underlying freedom of

\footnotetext{
${ }^{137}$ Government Administration Committee Inquiry into Censorship Issues, above n 131, at 19.

${ }^{138}$ Mary Kate McGowan “On 'Whites Only’ Signs and Racist Hate Speech: Verbal Acts of Racial

Discrimination" in Speech and Harm, above n 94, at 122.
} 
expression, political expression lies close to the core of the guarantee."139 They were required to consider the relationship between hate speech and political speech as the respondent argued that his flyers were "commentary on a social policy debate" at the core of protected expression. ${ }^{140}$ The Court was not particularly open to this argument, however: ${ }^{141}$

The expression captured under hate speech laws is of an extreme nature. Framing that speech as arising in a "moral" context or "within a public policy debate" does not cleanse it of its harmful effect. Indeed, if one understands an effect of hate speech as curtailing the ability of the affected group to participate in the debate, relaxing the standard in the context of political debate is arguably more rather than less damaging to freedom of expression. As argued by some interveners, history demonstrates that some of the most damaging hate rhetoric can be characterized as "moral", "political" or "public policy" discourse.

It too considered that merely because expression may be classed as political speech does not negate the possibility of it also constituting hate speech. ${ }^{142}$ They distinguished between hate speech "of a restrictive and exclusionary kind" and political expression, which "contributes to our democracy by encouraging the exchange of opposing views." 143 The Court also referred again to the speech-denying characteristic of hate speech, finding that "speech that has the effect of shutting down public debate cannot dodge prohibition on the basis that it promotes debate." 144

The Court made clear that hate speech legislation is not aimed at shutting down criticism of minority groups, even "repugnant or offensive ideas [or] expression which debates the merits of reducing the rights of vulnerable groups in society." 145 They spelled out that " $[\mathrm{t}]$ he polemicist may still participate on controversial topics that may be characterized as 'moral' or 'political'. However, words matter." ${ }^{\text {"146 }}$ A person critical of homosexual behaviour should be able to express that criticism, and engage in public debate where it arises. Equally, however, the court recognised "that the rights of a vulnerable group are a matter of ongoing discussion does not justify greater exposure by that group to hatred and its effects." 147 The Court clearly draws a distinction between

\footnotetext{
${ }^{139}$ Whatcott v Saskatchewan Human Rights Commission, above n 60, at [115].

${ }^{140}$ At [115].

${ }^{141}$ At [116].

${ }^{142}$ At [117].

${ }^{143}$ At [117].

${ }^{144}$ At [117].

${ }^{145}$ At [51].

${ }^{146}$ At [119].

${ }^{147}$ At [171].
} 
valid political expression, which may be critical or disagree with granting rights to minorities, and expression which uses political expression and public debate as a veiled excuse to vilify the minority group.

Applying such an interpretation to the submissions and publications regarding the New Zealand Marriage (Definition of Marriage) Amendment Act 2013, the vast majority would not be caught by hate speech legislation. Even those which argue against the extension of marriage rights would be able to express such sentiment freely. Although the submissions made by the Church of Jesus Christ of Latter Day Saints and Family First, for example, ${ }^{148}$ both disagree with the extension of marriage rights to GSM individuals, they do not seek to vilify that group to the extent required; their views do not personally attack gay or lesbian people as degenerate or subhuman. In comparison, the leaflets at Appendix 2 go far further in characterising a gay lifestyle as "risky and contagious", "bringing disease ... [and] early deaths and suicides" and corrupting children. ${ }^{149}$ These characteristics can be seen as falling within the 'hallmarks' of hatred set out in Warman. ${ }^{150}$ Thus the only submissions that would face hate speech penalties would be those which exposed the LGBT minority to hatred and contempt - those which dehumanised and vilified the group in "an extreme and marginal type of expression which contributes little to the values underlying freedom of expression." "As a result, the vast majority of political speech would continue to receive the protection of free expression.

\section{b) Humour}

Expression created in the guise of humour can, intentionally or unintentionally, attack a minority group. A recent New Zealand example was a Tui beer billboard advertisement which read "Dad's new husband seems nice - Yeah Right." The billboard was the subject of multiple complaints to the Advertising Standards Authority, on the basis that "the advertisement was homophobic; and called into question the validity of same-sex relationships." In handling the complaint, the ASA Chairman recognised that Tui ads were "well-known for making provocative statements across a wide spectrum of society

\footnotetext{
${ }^{148}$ Church of Jesus Christ of Latter Day Saints Outline of Position; Family First Submission (submissions to Government Administration Committee on Marriage (Definition of Marriage) Amendment Bill 2013), attached at Appendix 2.

${ }^{149}$ Anti-marriage equality leaflets mailed to MPs during the submission process of the Marriage (Definition of Marriage) Amendment Act 2013, as collected by David Farrar "Some anti same sex marriage correspondence" (12 April 2013) Kiwiblog

$<$ http://www.kiwiblog.co.nz/2013/04/some_anti_same_sex_marriage_correspondence.html) $>$, attached at Appendix 1.

${ }^{150}$ Warman $v$ Kouba, above n 120, at [124].

${ }^{151}$ Whatcott v Saskatchewan Human Rights Commission, above n 60, at [120].
} 
and about topical issues." ${ }^{, 152}$ Nevertheless, the ASA found no grounds to proceed with the complaint. Could such satirical humour be punished under hate speech legislation?

The Supreme Court in Whatcott considered, during their discussion of the words "ridicules or belittles", the place of humour in hate speech. They found that: ${ }^{153}$

Expression criticizing or creating humour at the expense of others can be derogatory to the extent of being repugnant. Representations belittling a minority group or attacking its dignity through jokes, ridicule or insults may be hurtful and offensive. However ... offensive ideas are not sufficient to ground a justification for infringing on freedom of expression.

... There may be circumstances where expression that "ridicules" members of a protected group goes beyond humour or satire and risks exposing the person to detestation and vilification on the basis of a prohibited ground of discrimination. In such circumstances, however, the risk results from the intensity of the ridicule reaching a level where the target becomes exposed to hatred.

If New Zealand were to follow Canada's lead on applying a restrictive interpretation of hate speech, it therefore seems likely that almost all humour and satire would continue to be free expression within the law.

\section{$4 \quad$ Alternatives to civil legislation}

\section{a) Marketplace of ideas}

One of the main alternatives offered is a 'marketplace of ideas', where all speech goes untrammelled and false, offensive or harmful speech can be countered and essentially shouted down by other ideas. As Laura Beth Nielsen recognises, "many legal scholars advocate unfettered free speech, claiming that individuals who are offended or harmed by speech can (and should) counter these bad effects with various kinds of 'more speech'." 154 She identifies that "consumers of ideas are expected to reject the bad ones, insert the better ones, and eventually prevail."155 However, Nielsen criticises this concept on the basis that it is "typically vague" and asks "what kind of speech effectively counters the "truth' of a racial epithet or a sexual slur?"156 Nielsen conducted

\footnotetext{
${ }^{152}$ Advertising Standards Authority Complaint Number 13/184 (15 May 2013).

${ }^{153}$ Whatcott $v$ Saskatchewan Human Rights Commission, above n 60, at [90]-[91].

${ }^{154}$ Laura Beth Nielsen "Power in Public: Reactions, Responses, and Resistance to Offensive Public Speech" in Speech and Harm, above n 94, at 148.

${ }^{155}$ At 154 .

${ }^{156}$ At 154-155.
} 
interviews with subjects and found that many reported unwillingness to respond to hate speech due to being fearful for their safety; those who were willing to engage were predominately white men "less likely to be physically vulnerable." 157 This indicates that for minorities, relying on a marketplace of ideas where the best response to hate speech is more speech, may not be appropriate or adequate to protect them from exposure to hatred.

The court in Whatcott also discussed the marketplace of ideas as an alternative: ${ }^{158}$

I do not say that the marketplace of ideas may not be a reasonable alternative, and where a legislature is so minded, it will not enact hate speech legislation. However, in Keegstra, Dickson CJ set out a compelling rationale for why Parliament's preference to regulate hate speech through legislation rather than to trust it to the hands of the marketplace was also reasonable. He noted that 'the state should not be the sole arbiter of truth, but neither should we overplay the view that rationality will overcome all falsehoods in the unregulated marketplace of ideas' ... While hate speech may achieve the self-fulfillment of the publisher, it does so by reducing the participation and self-fulfillment of individuals within the vulnerable group. These drawbacks suggest that this alternative is not without its concerns.

Nielsen's and Takach's research both indicate that the 'marketplace' is not safe for minorities to respond adequately to hate speech. Furthermore, as the court in Whatcott recognised, hate speech does not necessarily result in the 'search for truth' that the marketplace of ideas aims to nurture.

\section{b) Subsidised marketplace of ideas}

In response to the viewpoint that hate speech prevents minorities from responding to "speech which they find marginalizing or disempowering" Katharine Gelber has developed a policy proposal which she phrases as 'speaking back'. ${ }^{159}$ She characterises this proposal as one in which: ${ }^{160}$

[I]ndividuals who are the targets of hate speech are provided with the institutional, educational, and material support to enable them to speak back, both to counteract

\footnotetext{
${ }^{157}$ At 159 .

${ }^{158}$ Whatcott $v$ Saskatchewan Human Rights Commission, above n 60, at [104], quoting Dickson CJ $R v$ Keegstra [1990] 3 SCR 697 at 763.

${ }^{159}$ Katharine Gelber “'Speaking Back': The Likely Fate of Hate Speech Policy in the United States and Australia" in Speech and Harm, above n 94, at 51.

${ }^{160}$ Above.
} 
the messages contained within the hate speech and to counteract the effects of that speech on their ability to respond.

Gelber sees the outcome as shifting and recontextualising the hate speech policy debate, one which no longer binarily pits the speech opportunities of the hate speaker against the interests of the minority target. ${ }^{161}$ While she recognises that it does not directly punish the hate speaker, it "might do more to assist the targets" and aims to "[ameliorate] the effects of hate speech in such a way that the targets themselves are better able to engage in speech." "162 One of her key arguments in favour of such a policy is that it is not "speech-limiting or speech-restricting, it is speech-enhancing."

In analysing her proposed policy in the United States context, Gelber recognises that although 'speaking back' is speech-enhancing rather than speech-limiting, and could "promote and assist respectful interaction between human beings," 164 it may still be considered constitutionally invalid: ${ }^{165}$

[T] he idea that the speech of those who are disproportionately unable to speak might be supported to do so (even if it is in a way that does not restrict other speakers) has also been rejected by the Supreme Court.

Gelber attempts to construct ways in which the 'speaking back' policy could retain compatibility with First Amendment law, but ultimately recognises that for legal and 'political-pragmatic' reasons, the likelihood of such a programme to be achieved in the United States is "relatively bleak." 166

In contrast, such a policy in New Zealand would likely be considered legally valid and justified as a measure taken "in good faith" under s 19(2) of the Bill of Rights Act 1990. With that said, Gelber's consideration of 'political-pragmatic' reasons equally apply within the New Zealand context. She recognises that it "would require an allocation of public funds to the furtherance of specific anti-discriminatory messages in a manner which reaches beyond the historical or current commitments of many governments." ${ }^{\prime 167}$ While the New Zealand government provides funds for furtherance of human rights and anti-discrimination, such as funding the Human Rights Commission, it is doubtful that it would dedicate funding to this type of programme, especially as the proposal is aimed at

\footnotetext{
${ }^{161}$ Above.

${ }^{162}$ At 52 .

${ }^{163}$ At 55 .

${ }^{164}$ At 59 .

${ }^{165}$ At 56.

${ }^{166}$ At $62-63$

${ }^{167}$ At 62.
} 
providing assistance to "the individual target who experiences an incident of hate speech" rather than being framed as a general educational programme.

Gelber's proposal is also troubling in that it puts the onus on the minority victim of hate speech to avail themselves of the government support in publicly speaking back. While this would also be true to some extent where a victim can complain to a human rights agency, in the latter situation once a complaint is made the agency takes on the investigative and prosecutorial role. Gelber stresses that her policy aims to allow victims to "become able to respond by contradicting the messages ... and counteracting its effects." 168 What she fails to recognise is that in an environment saturated with residue of legalised and legislated hate speech against minorities, requiring a minority victim to individually speak out may well be easier said than done. As Waldron identifies: ${ }^{169}$

Why can't government presume that people's sense of the place of minorities in social life is resilient, even in the face of a proliferation of hateful material proclaiming the opposite? ... [T] he question answers itself, particularly in the context of a society that has a history of racism or intercommunal conflict. Nobody knows when that heritage of hate and conflict is really over.

While Waldron addresses the issue from the perspective of racial minorities, his comment is equally valid in the context of gender and sexual minorities. Homosexuality was only legalised in New Zealand in 1986, less than thirty years ago. ${ }^{170}$ Although the Marriage (Definition of Marriage) Amendment Act was passed earlier in 2013, it faced ferocious opposition from some quarters of society. Transgender individuals continue to face even more prejudice. Many prefer to keep their gender status private or shared only with those they implicitly trust, in order to avoid facing such prejudice and stigma. A GSM individual may feel confident and comfortable coming forward to take advantage of a 'speak out' funding programme, but equally, many would far rather stay silent than 'out' themselves publically. To protect vulnerable minorities, it is simply not enough to require them to speak out on their own behalf.

\section{c) Criminalising hate speech}

Some commentators suggest that "to minimally impair expression, hate speech should be dealt with through criminal law prohibitions or other prohibitions restricting only

\footnotetext{
168 At 69.

${ }^{169}$ Waldron, above n 92, at 153.

${ }^{170}$ Homosexual Law Reform Act 1986.
} 
speech which threatens, advocates or justifies violence." ${ }^{\prime 17}$ However, as the Court in Whatcott noted: ${ }^{172}$

The Commission argues that the Criminal Code provisions regulate only the most extreme forms of hate speech, advocating genocide or inciting a "breach of the peace". In contrast, human rights legislation "provides accessible and inexpensive access to justice" for disadvantaged victims to assert their right to dignity and equality.

If the amendments I have proposed were enacted, New Zealand law would maintain both criminal and civil hate speech legislation. However, s 131 aims to punish only the most egregious forms of hate speech. The requirement of intent, combined with the requirement for consent to prosecute from the Attorney-General, means that in practice the majority of hate speech will go unpunished. Civil provisions allowing investigation by the Human Rights Review Tribunal will provide more accessible justice for most complaints. Additionally, civil penalties are less punitive than fines and/or imprisonment. They emphasise conciliation and understanding between parties rather than legal punishment.

\section{Conclusion}

While hate speech legislation does create a conflict with freedom of expression, it is a conflict that can be justified and harmonised unless the constitutional framework is that in which free speech is paramount and cannot be balanced against other rights and freedoms. Any provision concerning hate speech must avoid overreaching into the realm of free expression. As a result, 'hate speech' should be clearly defined and narrowly focussed in scope, as words or matter which "exposes or tends to expose to hatred or contempt" the minority group at which the protection is aimed. In New Zealand's constitutional/rights framework, this limitation on freedom of expression can be justified as reasonable and appropriate. Although other options are available, none protect the minority group in question to the extent that hate speech limiting provisions would do so.

Furthermore, as the court in Whatcott recognised: ${ }^{173}$

Hate speech undermines the principles upon which freedom of expression is based and 'contributes little to the [...] quest for truth, the promotion of individual self-

\footnotetext{
${ }^{171}$ Whatcott $v$ Saskatchewan Human Rights Tribunal, above n 60, at [105].

${ }^{172}$ Above.

${ }^{173}$ At [104], quoting Dickson CJ in $R v$ Keegstra, above n 158, at 766.
} 
development or the protection and fostering of a vibrant democracy where the participation of all individuals is accepted and encouraged.'

To protect low-value speech which contributes so little, at the risk of perpetuating harm, discrimination, marginalisation and silencing of vulnerable minorities, is not appropriate. It sends the message that the voice of hate speakers is worth more than that of minorities, and undermines the implicit assurance that those minorities are welcome in and a valuable part of our society. 


\section{Bibliography}

A Legislation

$1 \quad$ New Zealand

Films, Videos, and Publications Classification Act 1993

Homosexual Law Reform Act 1986

Human Rights Act 1993

Marriage (Definition of Marriage) Amendment Act 2013

New Zealand Bill of Rights Act 1990

2 Australia

New South Wales Anti-Discrimination Act 1977

Tasmania Anti-Discrimination Act 1998

Racial Discrimination Act 1975

Queensland Anti-Discrimination Act 1991

\section{$3 \quad$ Canada}

Canadian Criminal Code (Canada), s 319

Canadian Human Rights Act (Canada), RSC 1985

Constitution Act 1982 (Canada), Part I, Canadian Charter of Rights and Freedoms

Statutes of Canada 2013, Chapter 37, Bill C-304 (An Act to amend the Canadian Human Rights Act (protecting freedom))

Saskatchewan Human Rights Code (Canada), s 14(1)(b)

$4 \quad$ South Africa

Promotion of Equality and Prevention of Unfair Discrimination Act 2000

$5 \quad$ United Kingdom

Human Rights Act 1998

Public Order Act 1986

B Cases

$1 \quad$ New Zealand 
Advertising Standards Authority Complaint Number 13/184 (15 May 2013).

Living Word Distributors Ltd v Human Rights Action Group Wellington [2000] 3 NZLR $570(\mathrm{CA})$.

$2 \quad$ Australia

Barry v Futter [2011] NSWADT 205.

Lange v Australian Broadcasting Corporation (1997) 189 CLR 520.

Owen v Menzies (2012) QCA 170.

Stephens $v$ West Australian Newspapers Ltd (1994) 182 CLR 211.

Sunol v Collier (No 2) [2012] NSWCA 44.

Theophanous $v$ Herald \& Weekly Times Ltd (1994) 182 CLR 104.

Veloskey v Karagiannakis [2002] NSWADTAP 18.

$3 \quad$ Canada

Canada (Human Rights Commission) v Taylor [1990] 3 SCR 892.

Canadian Human Rights Commission v Warman (2012) FC 1162.

R. v Oakes [1986] 1 SCR 103.

$R v$ Keegstra [1990] 3 SCR 697.

Warman v Kouba (2006) CHRT 50.

Whatcott v Saskatchewan Human Rights Tribunal (2013) SCC 11.

$4 \quad$ South Africa

Sonke Gender Justice Network v Malema (2010) (7) BCLR 729 (EqC).

$5 \quad$ United Kingdom

$R v$ O'Keefe [2003] All ER (D) 81 (Sep).

$6 \quad$ United States

National Socialist Party of America v Village of Skokie 432 US 43 (1977).

RAV v City of St Paul 505 US 377 (1992) at 381.

C Books and Papers

$1 \quad$ Books and chapters in books 
Katharine Gelber "'Speaking Back': The Likely Fate of Hate Speech Policy in the United States and Australia" in Speech and Harm: Controversies over Free Speech (Oxford University Press, Oxford, 2012) 50.

Evelyn Beatrice Hall The Friends of Voltaire (London, 1906).

Ishani Maitra "Subordinating Speech" in Ishani Maitra and Mary Kate McGowan Speech and Harm: Controversies over Free Speech (Oxford University Press, Oxford, 2012) 94.

Mary Kate McGowan “On 'Whites Only' Signs and Racist Hate Speech: Verbal Acts of Racial Discrimination" in Speech and Harm: Controversies over Free Speech (Oxford University Press, Oxford, 2012) 121.

Laura Beth Nielsen "Power in Public: Reactions, Responses, and Resistance to Offensive Public Speech" in Speech and Harm: Controversies over Free Speech (Oxford University Press, Oxford, 2012) 148.

Neil Rees, Katherine Lindsay and Simon Rice Australian Anti-Discrimination Law: Texts, Cases and Materials (Federation Press, Annandale, New South Wales, 2008).

Jeremy Waldron The Harm in Hate Speech (Harvard University Press, Cambridge, Massachusetts, 2012).

Caroline West "Words that Silence" in Speech and Harm: Controversies over Free Speech (Oxford University Press, Oxford, 2012) 222.

\section{Journal articles and other papers and articles}

"Anti-gay leaflets charge dropped" (28 September 2006) BBC News UK $<$ http://news.bbc.co.uk/2/hi/uk_news/wales/5388626.stm>.

Church of Jesus Christ of Latter Day Saints Outline of Position; Family First Submission (submissions to Government Administration Committee on Marriage (Definition of Marriage) Amendment Bill 2013)

David Farrar "Some anti same sex marriage correspondence" (12 April 2013) Kiwiblog $<$ http://www.kiwiblog.co.nz/2013/04/some_anti_same_sex_marriage_correspondence.ht $\mathrm{ml})>$. 
Asaf Fisher "Regulating Hate Speech" (2006) 8 UTS L Rev 21.

New Zealand Government Administration Committee Inquiry into Censorship Issues (March 2003) I.5A.

Office of Film and Literature Classification Submission: Inquiry into Hate Speech (29 October 2004).

Anne Scahill “Can Hate Speech Be Free Speech?” (1994) 4 Australasian Gay \& Lesbian LJ 1.

Statistics South Africa Quantitative Research Findings on Rape in South Africa (2000) $<$ http://www.statssa.gov.za $>$.

Ryan Takach "Gay and Lesbian Inequality: The Anti-Vilification Measures" (1994) 4 Australasian Gay \& Lesbian LJ 30. 


\section{Appendices}

A Appendix 1

- No legislation at all can effectively change an immoral, deadly disease-producing, non-procreative, costly, and often fatal lifestyle, into a truly moral, righteous, healthy, blessed, procreative, or even holy lifestyle.

- As you can easily assess these two lifestyles are two totally different ones and direct opposites - and can NEVER be legally and honestly treated as "equal" or the same e.g:

- one is safe: the other is not - but risky and contagious

- one is healthy: the other brings disease, infections or other medical \& psychological conditions

- one needs only a loving heart: the other requires that bondage of lust as well

- one is free: the other has costs e.g. condoms, HIV tests, PHARMAC or cancer treatments

- one brings new lives \& often longevity: the other brings early deaths \& suicides

- one brings our children \& descendants: the other brings none \& an empty barrenness

- one continues our Ancestral Family Trees: the other cuts them off

- one has a fulfilling painless coitus: the other resorts to anal sex or cunnilingus causing pain/s \& injuries

- one is done with a clear conscience:the other condemns bringing God-ordained guilt-repentance

- one is created \& blessed by God: the other is not but is cursed \& judged by God e.g. The Dead Sea of towns Sodom \& Gomorrah, \& buried Pompeili...now called quote; "The Sin City" \& "The City of Pornographic Erotica" (Google search, approx. 20111/12).

- One is a GENUINE: the other is a poor substitute, fake pseudo-'union', or sham

- Our God-ordained Heterosexual legally-consummated marriage, with its fully internal Love-Act of Procreation (quote; "one flesh" "union" see Mark 10:6-9) is the ONLY genuine harmonised marriage for Humans - as proved by our ancient Australian Aboriginal civilisation whose strict marriage Laws have protected them from Aids and extinction, so they are still with us today!

- To put it more bluntly, two vaginas do not a baby make - nor do two male sex organs!

Don't sacrifice our children as guinea pigs in a social engineering experiment. Today's teens haven't been taught 'gay is normal' - so may turn out $O K$. But if you vote pro gay:

\section{your family will think experimenting with gay sex is totally acceptable by you.}

Your future grandson will feel right kissing another man in front of you.

He'll feel right having sex with him in your home, because he believes you approve. Please protect our children.

Please vote for normal marriage - one man one woman.

It's on your shoulders.

Don't let an immature generation strip you of wisdom. Think of the damage at stake.

Anti-marriage equality leaflets mailed to MPs during the submission process of the Marriage (Definition of Marriage) Amendment Act 2013, as collected by David Farrar "Some anti same sex marriage correspondence" (12 April 2013) Kiwiblog $<$ http://www.kiwiblog.co.nz/2013/04/some_anti_same_sex_marriage_correspondence.ht $\mathrm{ml}>$. 
B Appendix 2 